\title{
ENERGY PROPERTIES OF WOOD PARTICLES TORREFIED AT DIFFERENT TEMPERATURES ${ }^{1}$
}

Carlos Miguel Simões da Silva ${ }^{2 *}$, Benedito Rocha Vital ${ }^{3}$, Angélica de Cassia Oliveira Carneiro ${ }^{3}$, Aylson

Costa Oliveira $^{4}$, Solange Oliveira Araújo ${ }^{5}$ and Mateus Alves de Magalhães ${ }^{2}$

\footnotetext{
${ }^{1}$ Received on 02.09.2014 accepted for publication on 11.11.2016.

${ }^{2}$ Universidade Federal de Viçosa, Programa de Pós-Graduação em Ciência Florestal, Viçosa, Minas Gerais, Brasil. E-mail: $<$ karmiguel@yahoo.com.br> and <mateusmagalhaes91@gmail.com>.

${ }^{3}$ Universidade Federal de Viçosa, Departamento de Engenharia Florestal, Viçosa, Minas Gerais, Brasil. . E-mail: <bvital@ufv.br $>$ and < cassiacarneiro@ufv.br>.

${ }^{4}$ Universidade Federal de Mato Grosso, Faculdade de Engenharia Florestal, Mato Grosso, Brasil. E-mail: <aylsoncosta@gmail.com>.

${ }^{5}$ Universidade de Lisboa, Centro de Estudos Florestais, Lisboa, Portugal. E-mail: <solangeeoa@yahoo.com.br>.

*Corresponding author.
}

\begin{abstract}
The objective of this study was to evaluate the effect of the final torrefaction temperature on the energy properties of wood. It was applied four treatments with three replicates, consisting of untreated wood particles and particles torrefied at temperatures of 170,220 and $260^{\circ} \mathrm{C}$. Better physical, chemical and thermal properties of the particles were observed as a function of the torrefaction temperature. Comparing with the control group, the particles torrefied at the highest final temperature $\left(260^{\circ} \mathrm{C}\right)$ showed significant differences in bulk density - from 239 to $396 \mathrm{~kg} / \mathrm{m}^{3}$; the equilibrium moisture content changed from 12.3 to $5.7 \%$; fixed carbon content - from 13.0 to $24.8 \%$; heating value - from 4,465 to $4,945 \mathrm{kcal} / \mathrm{kg}$; and energy density - from 882 to $1,727 \mathrm{Mcal} / \mathrm{m}^{3}$. It was concluded that torrefaction had a positive effect on the energy properties of the wood.
\end{abstract}

Keywords: Torrefaction; Higher Heating Value; Energy Properties.

\section{PROPRIEDADES ENERGÉTICAS DE PARTÍCULAS DE MADEIRA TORRIFICADAS EM DIFERENTES TEMPERATURAS}

\begin{abstract}
RESUMO-Objetivou-se neste estudo avaliar o efeito da temperatura final da torrefação nas propriedades energéticas da madeira. Foram aplicados quatro tratamentos com três repetições constituídos por partículas de madeira não torrificadas e partículas torrificadas nas temperaturas de 170,220 e $260^{\circ} \mathrm{C}$. Observaramse melhores propriedades fisicas, químicas e térmicas das partículas em função da temperatura de torrefação. Comparando com a testemunha, as particulas torrificadas na temperatura final mais elevada $\left(260^{\circ} \mathrm{C}\right)$ apresentaram diferenças significativas na densidade a granel - de 239 para $396 \mathrm{~kg} / \mathrm{m}^{3}$; umidade de equilibrio higroscópico - de 12,3 para 5,7\%; teor de carbono fixo - de 13,0 para 24,8\%; poder calorifico-de 4465 para 4945 $\mathrm{kcal} / \mathrm{kg}$; e densidade energética - de $882 \mathrm{para} 1727 \mathrm{Mcal} / \mathrm{m}^{3}$. Concluiu-se que a torrefação apresentou um efeito positivo nas propriedades energéticas da madeira.
\end{abstract}

Palavras-chave:Torrefação; Poder Calorifico Superior; Propriedades Energéticas. 


\section{INTRODUCTION}

Interest in clean and renewable sources of energy has grown in recent years as a result of the environmental and economic pressure on fossil fuels. The use of various biomasses appears as a promising alternative in this scenario. According to Vakkilainen et al. (2013), Brazil is currently the country that uses most of this energy source, with approximately $16 \%$ of the global use of biomass, followed by the United States ( $9 \%$ ) and Germany (7\%). Wood is the main biomass used by the energy sector in the country (Vital et al., 2013).

However, there are certain difficulties that prevent greater participation and competitiveness in the energy market of wood and other biomass, including the general properties inherent to it. In natura wood presents low heating value, high moisture content and heterogeneity (Sule, 2012). Torrefaction is one of the currently existing techniques that can minimize these limitations, a process by which the wood is subjected to a heat treatment between temperatures of 200 and $300^{\circ} \mathrm{C}$, in an atmosphere with low oxygen concentration. Under these conditions, in addition to the intense drying and the elimination of most of the extractives, there is a partial degradation of the structural components of the biomass. Although there is also a mass loss in lignin and cellulose, the thermal degradation of the hemicelluloses during torrefaction is much more intense and expressive (Bergman et al., 2005; van der Stelt et al., 2011; Koppejan et al., 2012; Lora et al., 2013).

While the hemicelluloses are mainly degraded between 200 and $260^{\circ} \mathrm{C}$, the thermal degradation of the cellulose occurs in a higher temperature range, from 240 to $350^{\circ} \mathrm{C}$, and that of lignin is characterized by a low mass loss due to the temperature increase and by a high percentage of residual mass (Carneiro et al., 2013; Oliveira et al., 2013). Lignin is the constituent with highest heating value due to its stability resulting from aromatic compounds and the high carbon content. Among polysaccharides, cellulose is more energetic due to its higher energy stability coming from its degree of polymerization and its partially crystalline structure (Vital et al., 2013).

The degraded fraction of these components during torrefaction is eliminated in the form of volatile materials, thereby concentrating the carbon in the final product. Thus, volatile materials are products of the preferential degradation of hemicelluloses, the least energetic structural component of wood. Therefore, the content of the components with the highest energy potential - mainly cellulose and lignin - is concentrated in the form of fixed carbon, increasing the heating value of the corresponding biomass (van der Stelt et al., 2011; Koppejan et al., 2012).

Direct consumption for energy generation is one of the main routes of consumption of torrefied biomass, be it in the co-combustion of pulverized coal or the association with other treatments or conversion routes, such as the production of pellets and gasification, adding more value to the end product (Koppejan et al., 2012).

In light of this, the objective of the present study was to evaluate the effect of the torrefaction temperature on the properties of energy interest, in wood particles of Eucalyptus sp., which is a type biomass that is very relevant for the Brazilian energy production sector.

\section{MATERIALAND METHODS}

It was used wood from 5.5 year-old Eucalyptus urophylla for the experimental procedure. The logs were peeled, broken down and then reduced to particles smaller than four millimeters in diameter by means of a hammer mill. The particles were then oven-dried with constant air circulation at a temperature of $100 \pm 3^{\circ} \mathrm{C}$ until reaching constant mass.

\subsection{Torrefaction}

The samples were treated in a rotating roaster consisting of a metal cylinder ( $0.7 \mathrm{~m}$ length by $0.5 \mathrm{~m}$ diameter $)$; an electric motor that turns it at an average rotation of $17 \mathrm{rpm}$ and a heating system by means of burning of gas (LPG), powered by two cylinders of $13 \mathrm{~kg}$ connected in parallel. The temperature was monitored through an analog thermometer installed in the cylinder and controlled through a gas inlet regulator register and another air intake regulator.

The heating rate was approximately $5^{\circ} \mathrm{C} / \mathrm{min}$, keeping the material for a further 15 minutes at the desired final temperature. After this time, the heating system was shut down and the metal cover removed, keeping the cylinder in constant rotation until the material cooled to below $50^{\circ} \mathrm{C}$, in order to prevent any combustion of the torrefied material when exposed to ambient oxygen.

\subsection{Properties of Biomass}

Bulk density was determined by filling a vessel with an internal volume of $0.001 \mathrm{~m}^{3}$ with the particulate 
samples of each treatment after equilibration at $65 \%$ relative humidity and $20^{\circ} \mathrm{C}$ temperature. The density calculation was done by dividing the mass of the sample $(\mathrm{kg})$ by the internal volume of the box $\left(\mathrm{m}^{3}\right)$.

In order to determine the equilibrium moisture content, the samples were placed in a climatic chamber at $20^{\circ} \mathrm{C}$ temperature and $65 \%$ relative humidity until reaching a constant mass. The moisture was calculated on dry basis following the standards prescribed by ABNT NBR 9484 (ABNT, 1986).

The immediate chemical composition was obtained from ground samples, sieved in a grain size between 40 and $60 \mathrm{mesh}$, and dried at $0 \%$ moisture following the procedures cited by ABNT NBR 8112 (ABNT, 1983), with some adaptations for the determination of volatile material contents, ash and fixed carbon.

The higher heating value (HHV) was determined using a calorimetric pump, following the standards of ABNT NBR 8633 (ABNT, 1984). Particle samples were ground in a knife mill, selected from a set of overlapping sieves of 40 and 60 mesh, and then dried to $0 \%$ moisture.

The energy density $\left(\mathrm{kcal} / \mathrm{m}^{3}\right)$ was estimated by multiplying the energy content $(\mathrm{kcal} / \mathrm{kg})$ by the average density $\left(\mathrm{kg} / \mathrm{m}^{3}\right)$ of the samples in each treatment. As the density used was in bulk, the energetic content considered was the net heating value (NHV), which discounts the energy expended to evaporate the water present in the samples. The NHV was estimated by the formulas cited by Brito (1993):

(i) $\mathrm{NHV}=[\operatorname{LHV}(1$ “ M) $]$ “ (600M)

(ii) $\mathrm{LHV}=\mathrm{HHV}$ “ $[600(9 \mathrm{H} / 100)]$

In which: $\mathrm{H}$ - Hydrogen (\%); M - moisture, LHV - lower heating value ( $\mathrm{kcal} / \mathrm{kg}$ ). The moisture considered for the samples was the average of the values obtained in the estimations of the equilibrium moisture content (EMC) for the wood samples submitted to each of the treatments. The conversion to LHV is necessary to disregard the energy expended with the evaporation of the water due to the oxidation of the fuels that present hydrogen in their composition.

\subsection{Mass and Energy Yield}

The mass yield for each treatment was obtained by dividing the final mass (torrefied particles) by the initial mass (in natura wood particles) for each torrefaction (repetition) and multiplying by 100 .

The energy yield for each treatment was obtained by dividing the HHV of the torrefied particles by the average HHV value obtained for the in natura wood and multiplying it by the mass yield.

\subsection{Experimental Design}

The experiment consisted of a completely randomized design with four treatments and three replications, as follows:

- T1 - Ambient-dried but not torrefied particles;

- T2 - Wood particles pre-torrefied up to the final temperature of $170 \pm 5^{\circ} \mathrm{C}$.

- T3 - Wood particles torrefied up to the final temperature of $220 \pm 5^{\circ} \mathrm{C}$.

- T4 - Wood particles torrefied up to the final temperature of $260 \pm 5^{\circ} \mathrm{C}$.

After confirming the normality and homogeneity of the data variance for each treatment, they were submitted to analysis of variance (ANOVA) and, when significant differences were established, the treatments were then compared by means of the Tukey test, at $5 \%$ probability.

\section{RESULTS}

Table 1 shows the average mass yields for the treatments and their respective average bulk density and equilibrium moisture content values.

According to the values described in Table 1, it was observed that torrefaction influenced the bulk density of the wood particles, with a positive correlation with the final torrefaction temperature. The samples of non-torrefied particles (T1) presented a significant difference with the average density values of the others samples, which had been torrefied. However, although the T2, T3 and T4 particles presented statistical differences between them, there were no numerical differences as discrepant as with the control sample. There was approximately $37 \%$ increase between the densities in $\mathrm{T} 1$ and $\mathrm{T} 2$, while the increase between $\mathrm{T} 2$ and $\mathrm{T} 4$ was of less than $5 \%$.

Table 2 shows the average values of the immediate chemical composition of the wood as a function of the treatments. 
Table 1 - Average values for bulk density and equilibrium moisture content (EMC) of wood samples subjected to different treatments.

Tabela 1 - Valores médios de densidade a granel e de umidade de equilibrio higroscópico (EMC) das amostras de madeiras submetidas a diferentes tratamentos.

\begin{tabular}{ccc}
\hline Treatment & Bulk density $\left(\mathrm{kg} / \mathrm{m}^{3}\right)$ & EMC $(\%)$ \\
T1 & $239.1 \mathrm{c}$ & $12.3 \mathrm{a}$ \\
T2 & $377.8 \mathrm{~b}$ & $9.2 \mathrm{~b}$ \\
$\mathbf{T 3}$ & $384.6 \mathrm{ab}$ & $6.5 \mathrm{c}$ \\
T4 & $396.0 \mathrm{a}$ & $5.7 \mathrm{~d}$ \\
\hline
\end{tabular}

Averages followed by the same letter in the column do not differ from one another at $5 \%$ probability by Tukey's test.

Table 2 - Average values for volatile matter (VM), fixed carbon (FC) and ash (A) obtained from the wood particles subjected to different treatments.

Tabela 2 -Valores médios de materiais voláteis (VM), carbono fixo $(F C)$ e cinzas $(A)$ das particulas de madeira submetidas a diferentes tratamentos.

\begin{tabular}{cccc}
\hline Treatment & VM $(\%)$ & FC (\%) & A (\%) \\
\hline T1 & $86,8 \mathrm{a}$ & $13,0 \mathrm{~d}$ & $0,16 \mathrm{a}$ \\
T2 & $84,4 \mathrm{~b}$ & $15,4 \mathrm{c}$ & $0,19 \mathrm{a}$ \\
T3 & $80,9 \mathrm{c}$ & $18,9 \mathrm{~b}$ & $0,19 \mathrm{a}$ \\
T4 & $75,0 \mathrm{~d}$ & $24,8 \mathrm{a}$ & $0,21 \mathrm{a}$ \\
\hline
\end{tabular}

Averages followed by the same letter in the column do not differ from each other at $5 \%$ probability by Tukey's test.

According to the averages presented in Table 2, there was a reduction in the content of volatile materials with the increase of the final torrefaction temperature, and consequently an increase in the fixed carbon content. Fixed carbon increased from $13.0 \%$ in the $\mathrm{T} 1 \mathrm{samples}$ to $26.7 \%$ in the $\mathrm{T} 4$ samples.

There was no significant effect of the temperature on the ash content, which remained close to $0.2 \%$.

Table 3 summarizes the average energy values for the samples in each treatment.

Table 3 - Average values for Higher Heating Value (HHV) and Energy Density of the samples submitted to different treatments.

Tabela 3 -Valores médios de poder calorifico superior (HHV) e densidade energética das amostras submetidas a diferentes tratamentos.

\begin{tabular}{ccc}
\hline Treatment & $\begin{array}{c}\text { HHV } \\
(\mathrm{kcal} / \mathrm{kg})\end{array}$ & $\begin{array}{c}\text { Energy Density } \\
\left(\mathrm{Mcal} / \mathrm{m}^{3}\right)\end{array}$ \\
\hline T1 & $4465.0 \mathrm{~d}$ & $882 \mathrm{~d}$ \\
T2 & $4570.1 \mathrm{c}$ & $1440 \mathrm{c}$ \\
T3 & $4772.7 \mathrm{~b}$ & $1593 \mathrm{~b}$ \\
T4 & $4945.0 \mathrm{a}$ & $1727 \mathrm{a}$ \\
\hline
\end{tabular}

Averages followed by the same letter in the column do not differ from each other at $5 \%$ probability by Tukey's test.
The heating value of the particles presented a directly proportional increase with the final torrefaction temperature. The obtained average values showed significant differences across the treatments, with a gradual increase of almost $11 \%$ from T1 to T4.

Table 4 shows the average values of mass and energy yield for each treatment.

Significant differences were observed in both the Mass Yield and in the Energy Yield of the treatments, on a dry basis, and there was a reduction due to the increase in temperature.

\section{DISCUSSIONS}

It was observed a reduction in particle size during torrefaction, which probably led to a more compact overlap of the particles, presenting a more complete occupation of the free spaces. Therewith, the bulk density of the material is raised. The numerically larger difference between the density of the in natura and the torrefied particles may be due to the contraction caused by the drying of the particles during the first stage of torrefaction (Oliveira et al., 2010).

According to van der Stel et al. (2011), torrefaction reduces the tenacity of the particles, mainly by the degradation of hemicelluloses and causing a partial destruction of the structure of the biomass, making it more fragile and brittle. It is possible that this fragility generated smaller particles, explaining the difference in density between T2, T3 and T4.

The equilibrium moisture content of the samples decreased as a result of the final temperature in which they were torrefied, demonstrating the hygroscopicity of the samples due to the reduction of the hydroxyl groups available for hydrogen bonding with water molecules in the biomass structure. The higher thermal degradation of the hemicelluloses and the consequent

Table 4 - Mass and Energy Yields for the different treatments. Tabela 4 - Rendimento em massa e energia para os diferentes tratamentos.

\begin{tabular}{ccc}
\hline \multirow{2}{*}{ Treatment } & \multicolumn{3}{c}{ Yield (\%) } \\
\cline { 2 - 3 } & Mass & Energy \\
\hline T1 & $100.0 \mathrm{a}$ & $100.0 \mathrm{a}$ \\
T2 & $96.8 \mathrm{~b}$ & $99.0 \mathrm{a}$ \\
T3 & $89.1 \mathrm{c}$ & $95.2 \mathrm{~b}$ \\
T4 & $75.7 \mathrm{~d}$ & $83.9 \mathrm{c}$ \\
\hline
\end{tabular}

Averages followed by the same letter in the column do not differ from each other at $5 \%$ probability by Tukey's test. 
concentration in the lignin contents have a direct influence on the reduction of the hygroscopicity of the torrefied particles. Hemicelluloses are more hydrophilic because they contain a greater amount of hydroxyl groups. On the other hand, lignin is the most hydrophobic structural constituent of wood, effectively contributing to reduce its water absorption from the environment (Rowell et al., 2005).

Increasing the bulk density and reducing the moisture and hygroscopicity of the particles according to the torrefaction temperature, results in better properties and handling, transport, storage and end-use performance of the torrefied material (Sule, 2012).

The increase in the fixed carbon content is due to the greater intensity of degradation of the hemicelluloses which occurred in the temperature ranges of the torrefaction, thus favoring the percentage concentration of the lignin in the material, the constituent with the highest carbon content in the composition (Vital et al., 2013 ).

According to Koppejan et al. (2012), lignocellulosic biomass generally contains approximately $80 \%$ of volatile materials and $20 \%$ of fixed carbon but during torrefaction, there is a removal of about $20 \%$ of that volatile fraction. The trend of fixed carbon concentration as a result of the increased temperature of treatment was also verified by other authors, such as Rodrigues (2010) and Felfli et al. (2005).

The increase in the heating value of $\mathrm{T} 1$ to $\mathrm{T} 4$ is proportionally similar to those cited by Rodrigues and Rousset (2010) who found an increase from 4,674 to 5,121 kcal/ $\mathrm{kg}$ between pieces of in natura wood and pieces torrefied at $250^{\circ} \mathrm{C}$. Koppejan et al. (2012) reported a similar increase of 4,538 to more than $5,015 \mathrm{kcal} / \mathrm{kg}$ as a result of torrefaction. The higher fixed carbon content generated the increase in the heating value of the torrefied particles.

The same tendency was observed for energy density. However, there was a larger increase, almost twice as high, between the first and the last treatment. This increase was already expected because the increase in $\mathrm{HHV}$, the increase in bulk density and the reduction of equilibrium moisture directly influence the energy density due to the variables considered in their estimates.

The increase in the energy quality of the torrefied particles results from the higher carbon content in the composition, as previously mentioned in Table 2 . The higher HHV means more energy per mass unit and the higher the energy density, the higher the energy pervolume unit. These increases guarantee better yields during transportation, storage and especially the end consumption of these products (Sule, 2012).

Rodrigues and Rousset (2010) obtained yields higher than $80 \%$, and the possible explanation for this difference is that this author uses pieces of wood with dimensions of $4 \times 2 \times 8 \mathrm{~cm}$. Larger pieces are more difficult to degrade by the action of the torrefaction temperature when compared to the wood particles used in the present study.

It should be noted that the energy yield of solid torrefied materials, as suggested by Bergman et al. (2005) is situated in the range of 80 to $95 \%$, so the value obtained in the present study can be considered satisfactory.

Unlike pyrolysis, which achieves higher temperatures degrading practically all polysaccharides, torrefaction maintains the most energetic components of the source material and presents energy yields higher than the referred treatment. There is a mass loss in hemicelluloses, which have an approximate average $\mathrm{HHV}$ of $3,800 \mathrm{kcal} / \mathrm{kg}$ but the lignin that presents a higher HHV, usually between 5,000 and $6,450 \mathrm{kcal} / \mathrm{kg}$ is maintained (Vital et al., 2013).

\section{CONCLUSIONS}

Torrefied particles of Eucalyptus urophylla have higher bulk density, lower moisture and hygroscopicity, higher fixed carbon content and lower volatile matter as a function of the final torrefaction temperature.

The torrefied particles have a higher energy potential both per unit mass and per unit volume, i.e. higher heating value and higher energy density, respectively. The energy yield of the torrefied particles is greater than the mass yield indicating that the less energetic constituents are preferentially degraded.

Among the final torrefaction temperatures evaluated in the present study, the particles torrefied at $260^{\circ} \mathrm{C}$ were the ones that presented the best energetic characteristics, with yields within the acceptable limits. Therefore, among the four treatments evaluated, it is the material that presents the greatest competitiveness within energy market.

\section{ACKNOWLEDGMENTS}

The authors would like to thank FAPEMIG (Foundation for Research Support of the State of Minas Gerais) for their financial support; to CNPq (National

Revista Árvore. 2017;41(4):e410404 
Research Council) and to Embrapa Florestas for granting of the research grants.

\section{REFERENCES}

Associação Brasileira de Normas Técnicas ABNT. NBR 8112: Carvão vegetal - análise imediata. Rio de Janeiro: 1983.

Associação Brasileira de Normas Técnicas ABNT. NBR 8633: Carvão vegetal: determinação do poder calorífico. Rio de Janeiro: 1984.

Associação Brasileira de Normas Técnicas ABNT. NBR 9484: Compensado - determinação do teor de umidade. Rio de Janeiro: 1986.

Bergman PCA et al. Torrefaction for entrainedflow gasification of biomass. ECN. 05-067. 2005.

Brito JO. Expressão da produção florestal em unidades energéticas. In: Anais do $1^{\circ}$ Congresso Florestal Panamericano; $7^{\circ}$. Congresso Florestal Brasileiro. Curitiba: 1993. p.280-2.

Carneiro ACO et al. Conversão direta da madeira em calor e energia. In: Santos F., Colodette J, Queiroz JH, editores. Bioenergia \& biorrefinaria cana-de-açúcar \& espécies florestais". Viçosa, MG: 2013. p.355-78.

Felfli FF, Luengo CA, Suarez JA, Beaton PA. Wood briquette torrefaction. Energy for Sustainable Development. 2005; 9:20-3.

Koppejan J et al. Status overview of torrefaction technologies. IEA Bioenergy Task 32. 2012.

Lora EES, Venturini OJ, Andrade RV. Torrefação de madeira. In: Santos F, Colodette J, Queiroz JH, editores. Bioenergia \& biorrefinaria - cana-de- açúcar \& espécies florestais”. Viçosa, MG: 2013. p.401-27.

Oliveira JTS, Tomazello Filho M, Fiedler NC. Avaliação da retratibilidade da madeira de sete espécies de Eucalyptus. Revista Árvore. 2010;34:929-36.

Oliveira AC et al. Otimização da produção do carvão vegetal por meio do controle de temperaturas de carbonização. Revista Árvore. 2013;37:557-66.

Rodrigues TO, Rousset PLA. Effects of Torrefaction on energy properties of Eucalyptus grandis Wood. Cerne. 2010;15:446-52.

Rowell RM, Levan-Green S. Thermal properties. In: Rowell R.M., editor. Hand book of wood chemistry and wood composites. Boca Raton: CRC Press; 2005. p.121-38.

Sule IO. Torrefaction behaviour of agricultural biomass [dissertation]. Guelph: The University of Guelph; 2012.

Vakkilainen E, Kuparinen K, Heinimö J. Large industrial users of energy biomass. IEA Bioenergy Task 40. 2013.

van der Stelt MJC, Gerhauser H, Kiel JHA, Ptasinski KJ. Biomass upgrading by torrefaction for the production of biofuels: A review. Biomass \& Bioenergy. 2011;35:3748-62.

Vital BR, Carneiro ACO, Pereira BLC. Qualidade da madeira para fins energéticos. In: Santos $F$, Colodette J, Queiroz J.H, editores. Bioenergia \& biorrefinaria - cana-de-açúcar \& espécies florestais". Viçosa, MG: 2013. p.321-54.

\section{ERRATA}

\section{No artigo "ENERGY PROPERTIES OF WOOD PARTICLES TORREFIED AT DIFFERENT}

TEMPERATURES”, publicado no número 4, volume 41, da Revista Árvore, onde se lê: http://dx .doi.org/10.1590/1806-90882017000200004

L eia-s e:

http://dx .doi.org/10.1590/1806-90882017000400004 
onde se lê:

${ }^{5}$ Universidade Técnica de Lisboa, Centro de Estudos Florestais, Lisboa, Portugal. E-mail: $<$ solangeeoa@yahoo.com.br>.

L eia- s e:

${ }^{5}$ Universidade de Lisboa, Centro de Estudos Florestais, Lisboa, Portugal. E-mail: <solangeeoa@yahoo.com.br>. 